\title{
KAJIAN PERSEPSI KONSUMEN TERHADAP PELAYANAN JASA PENYEWAAN LAPANGAN FUTSAL (Survey pada Aras Futsal Kota Pekanbaru)
}

\author{
Murnawati \\ Fakultas Ekonomi Universitas Lancang Kuning \\ Jln. D.I. Panjaitan KM 8 Rumbai Pekanbaru \\ E-mail : murnawati@unilak.ac.id
}

\begin{abstract}
Exercise is the need of every human being in life to keep his physical condition and health well preserved. Modern lifestyle requires people to spend more time to work Futsal as an alternative sport is now one of the most popular sports in Indonesia including in Pekanbaru City. Evidenced by the proliferation of futsal playing arena and business competition futsal field rental services in every corner of Pekanbaru City that customer satisfaction will be fulfilled if the process of delivering services from providers to consumers in accordance with what perceived consumers, This research is descriptive research, the method used is survey method, the poplation is the customer who use the service on futsal arak field, while the sampling technique using Accidental Sampling, by using questionnaire while to analyze the data by using descriptive technique of this research using the formula of mean (Average) and percentage.Skala (measuring tool) respondents using a scale scale Linkert or determination scale and can be used as starting point to make the instrument in the form of questions that need to be aanswered by therespondent
\end{abstract}

Keywords: consumer perception, service quality

\section{PENDAHULUAN}

Olahraga merupakan kebutuhan setiap manusia di dalam kehidupan agar kondisi fisik dan kesehatannya tetap terjaga dengan baik. Gaya hidup dijaman moderen menuntut manusia akan lebih banyak menghabiskan waktunya untuk bekerja. Situasi dan kondisi di atas menjadikan aktifitas olahraga sangat sulit dilakukan dan hanya bisa dilakukan bila memiliki waktu luang.

Olahraga futsal menjadi salah satu pilihan untuk menjaga kebugaran atau kesehatan di daerah perkotaan, futsal saat ini menjadi olahraga favorit karena permainan melibatkan banyak orang, dan dapat digunakan sebagai sarana sosialisasi dan tempat berkumpul dengan teman serta menjadi salah satu tempat berkumpul favorit setelah melakukan aktivitas di kampus atau di kantor. Hobi bermain futsal nampaknya semakin diminati mulai anak-anak hingga orang dewasa, di kota besar atau daerah. Hal ini terlihat dari antrian dari kelompak karyawan, mahasiswa dan bahkan siswa SMA yang datang silih berganti di jasa penyewaan lapangan futsal. Pengusaha yang jeli melihat peluang usaha ini akan mengalokasikan modalnya dengan berlomba-lomba mendirikan usaha jasa penyewaan lapangan futsal

Setiap konsumen atau penyewa jasa pelayanan lapangan futsal akan mengharapkan fasilitas yang lengkap, pelayanan yang baik dan harga yang terjangkau, tetapi dalam kenyataannya yang ditemukan masih banyak jasa lapangan futsal yang tidak sesuai dengan yang diharapkan oleh konsumen, harga yang ditawarkan tidak sesuai dengan fasilitas dan mutu dari lapangan futsal tersebut, sehingga mengecewakan atau menimbulkan rasa tidak puas. 
Dengan melakukan wawancara terhadap salah satu konsumen jasa penyewaan lapangan futsal di pekanbaru , ternyata masih ada jasa penyewaan lapangan futsal yang masih belum memenuhi harapan konsumen. Harapan konsumen tidak terpenuhi sesuai harapan terlihat dari fasilitas yang ada tidak sesuai dengan harga yang diberikan oleh jasa penyewaan lapangan futsal. Harapan konsumen yang tidak terpenuhi mengakibatkan konsumen mengalami kekecewaan dan yang mengakibatkan konsumen tidak merasa puas dan merasa ditipu oleh salah satu jasa penyewaan lapangan futsal.

Keberhasilan suatu perusahaan sangat dipengaruhi oleh bagaimana perusahaan tersebut memberi kepuasan dan kebahagiaan kepada pelanggan. Perusahaan sebagai individu dalam suatu sistem memfokuskan kegiatan kepada pelanggan sebagai konsumen jasa, agar dapat lebih efektif dan efisien dalam menjalankan kegiatan dalam memberikan atau menyediakan jasa maupun produk yang berkualitas

\section{TINJAUAN PUSTAKA}

Menurut Eysenck dalam ansori (2009:215) menyatakan bahwa persepsi sesungguhnya memerlukan proses belajar, dan pengalaman, hasil proses belajar dan interaksi seseorang akan memberikan pengalaman bagi dirinya untuk dapat membandingkan keadaan yang dihadapi

\begin{tabular}{lrr}
\multicolumn{1}{c}{ Faktor } & yang mempengaruhi \\
Persepsi & Menurut & Miftah \\
Toha(2003:154) & menyatkan & bahwa \\
faktor yang mempengaruhi & persepsi
\end{tabular}
seseorang adalah sebagai berikut : a. Faktor internal yaitu Perasaan, sikap, dan kepribadian individu, prasangka , keinginan, atau harapan perhatian, (focus) proses belajar, keadaan fisik , gangguan kejiwaan nilai dan kebutuhan juga minat dan motivasi b. Faktor
Ekternal yaitu berasal dari, latar belakang keluarga, informasi yang diperoleh, pengetahuan dan kebutuhan sekitar, intensitas, ukuran, keberlawanan, pengulangan gerak, atau ketidak asingan suatu objek

Menurut Swastha dan $\mathrm{T}$ Hani Handoko (2000: 12) konsumen adalah individu-individu yang melakukan pembelian untuk memenuhi kebutuhan pribadi atau konsumsi rumah tangga. Pelanggan adalah orang, instansi atau lembaga yang membeli barang atau jasa secara rutin atau berulang-ulang. Dari pengertian di atas konsumen atau pelanggan merupakan perhatian dalam pembahasan mengenai kepuasan dan kualitas jasa karena konsumen sumber utama untuk mengukur kepuasan terhadap produk maupun pelayanan yang diberikan perusahaan.

Dimensi kwalitas pelayanan menurut Lupiyoadi 2001:148) yaitu: 1,Tagible (bukti Fisik) yaitu kemampuan suatu perusahaan dalam menunjukkan eksistensinya kepada pihak ekternal, penampilan dan kemampuan sarana dan prasarana fisik perusahaan dan keadaan lingkungan sekitarnya. 2. Reliability (Kehandalan) yaitu kemampuan perusahaan untuk memberikan pelayanan sesuai yang dijanjikan secara akurat dan terpercaya kinerjanya harus sesuai dengan harapan pelanggan yang berarti ketepatan waktu pelayanan yang sama untuk semua pelanggan tanpa kesalahan 3 . Responsivenes (ketanggapan) yaitu kemauan untuk membantu dan memberikan pelayanan yang cepat (Responsif) dan tepat kepada pelanggan dengan menyampaikan informasi yang jelas. 4 Assurance (Jaminan dan kepastian) yaitu pengetahuan kesopansantunan, dan kemampuan para pegawai perusahaan untuk menumbuhkan rasa percaya para pelangan kepada perusahaan terdiri dari beberapa komponen antara lain komunikasi, kredibilitas, keamanan, dan sopan santun 


\section{Jurnal Ilmiah Ekonomi dan Bisnis}

Vol. 15. No.1, Maret 2018: 84-88

EISSN : $2442-9813$

ISSN : 1829-9822

5. Emphaty (empati) yaitu memberikan perhatian yang tulus dan bersifat individual atau pribadi yang memberikan kepada para pelanggan dengan berupaya memahami keinginan konsumen dimana suatu perusahaan diharapkan memiliki pengertian dan pengetahuan tentang pelanggan, serta memiliki waktu untuk pengoperasiaanya yang nyaman bagi pelanggan.

Menurut Justinus Lhaksana (2011:7) futsal adalah permainan yang sangat cepat dan dinamis dengan passing yang akurat yang memungkinkan terjadinya banyak gol, dari segi lapangan yang relative kecil hampir tidak ada yang membuat kesalahan, futsal adalah olah raga beregu, kelektifitas tinggi akan menganggkat prestasi

\section{METODE PENELITIAN}

Penelitian tentang kepuasan konsumen terhadap jasa pengelolaan lapangan futsal merupakan penelitian deskriptif dengan menggunakan metode survei, adapun pengumpulan datanya dengan menggunakan angket.

Populasi dalam penelitian ini adalah konsumen atau pemakai jasa lapangan futsal di Aras Futsal. Dalam penelitian ini ditetapkan sampel yang digunakan adalah 30 konsumen jasa Penyewaan lapangan di Aras Futsal. Instrumen yang digunakan dalam penelitian ini adalah kuesioner yang berbentuk angket. Angket tersebut berisi butir-butir pernyataan untuk diberi tanggapan oleh responden.

Analisa data digunakan metode deskriptif dimana data yang digunakan berhasil dikumpulkan dan selanjutnya akan dikelompokkan dan dipisahkan sesuai dengan jenisnya dan dianalisa secara kwantitatif yang disajikan dalam bentuk tabel dan uraian, Dalam menguji kedua rumusan masalah,

\section{HASIL DAN PEMBAHASAN}

Identifikasi faktor yang paling dominanan dalam persepsi konsumen pengguna jasa lapangan futsal di Aras futsal, penggunaan persentase yaitu dari hasil rata-rata seluruh jawaban konsumen pada masing-masing indicator akan di persentasekan dengan skor Maksimal (190 adalah skor Maksimal dari penjumlahan item pernyataan dengan skala jawaban yang terbesar)

Tabel 1. Hasil jumlah skor dan rata-rata dan persentase seluruh indicato

\begin{tabular}{|c|c|c|c|}
\hline No & indikator & $\begin{array}{l}\text { Rata- } \\
\text { rata }\end{array}$ & Persentase \\
\hline 1 & $\begin{array}{lll}\text { pada indicator Tanggibel } & \text { (bukti } \\
\text { Fisik) Yaitu kemampuan } & \\
\text { kemampuan perusahaan } & \text { dalam } \\
\text { menunjukkan eksistensinya } & \end{array}$ & 55,46 & $29,18 \%$ \\
\hline 2 & \begin{tabular}{lcrr} 
pada indicator & \multicolumn{2}{r}{ Reability } \\
(Kehandalan)Yaitu & \multicolumn{2}{c}{ kemampuan } \\
perusahaan dalam & \multicolumn{2}{c}{ memberikan } \\
Pelayanan sesuai & dengan & yang \\
dijanjikan & secara & akurat & dan \\
terpercaya & & &
\end{tabular} & 35,30 & $18,57 \%$ \\
\hline 3 & $\begin{array}{l}\text { pada indicator Responsivenes } \\
\text { (Ketanggapan) Yaitu Kemauan } \\
\text { untuk membantu dan memberikan } \\
\text { pelayanan }\end{array}$ & 24,23 & $12,75 \%$ \\
\hline 4 & $\begin{array}{l}\text { Assurance (Jaminan dan Kepastian) } \\
\text { yaitu pengetahuan, kesopan } \\
\text { santunan dan kemampuan para } \\
\text { pegawai perusahaan utuk untuk } \\
\text { menumbuh rasa percaya para } \\
\text { pelanggan kepada perusahaan }\end{array}$ & 29,90 & $15,73 \%$ \\
\hline 5 & $\begin{array}{l}\text { pada indicator Emphaty (empati) } \\
\text { Yaitu memberikan perhatian yang } \\
\text { tulus dan bersifat indifidual }\end{array}$ & 18,1 & $9,52 \%$ \\
\hline & Total & 163 & $85,93 \%$ \\
\hline
\end{tabular}

Sumber : Data Olahan penelitian

Dari hasil perhitungan diatas dengan menggunakan persentase menunjukkan bahwa yang paling dominan yang mempengaruhi persepsi konsumen terhadap palayanan jasa penyewaan lapangan futsal adalah indicator bukti fisik yaitu kemampuan perusahaan dalam menunjukkan eksistensinya sebesar $29,18 \%$, dari berbagai variabel yang ada total keseluruhan yang diperoleh adalah $85,93 \%$ menunjukkan rata-rata perentase konsumen menyatakan sangat baik pada indicator Reability (Kehandalan)Yaitu kemampuan perusahaan dalam memberikan Pelayanan sesuai dengan yang dijanjikan 
secara akurat dan terpercaya, pelayanan yang baik dapat dilihat dari kemampuan yang dimiliki karyawan pada saat ia memberikan jasa secara terpercaya dan akurat.

Kepuasan konsumen merupakan tingkat perasaan seseorang yang melakukan pembeliaan produk atau jasa untuk kebutuhan pribadinya setelah melakukan perbandingan antara kinerja produk atau jasa yang diberikan terhadap apa yang diharapkan oleh pemakai ataupun pelaku jasa tersebut. Kepuasan dapat dipengaruhi oleh pelayanan yang diberikan kepada konsumen. Assurance (Jaminan dan Kepastian) pada aras futsal seperti keamanan barang bawaan, keamanan lingkungan sekitar, keramahan karyawan, kesopanan dan perilaku karyawan, mereka mampu meyakinkan konsumen dalam memberikan pelayanan yang ramah kepada konsumen, seperti terlihat pada jawaban respondence yang menyatakan adalah sangat baik, artinya dalam melaksanakan pekerjaan selalu berupaya memberikan pelayanan yang ramah kepada konsumen

$$
\text { Emphaty (empati) Yaitu }
$$

memberikan perhatian yang tulus dan bersifat indifidual konsumen pengguna jasa lapangan futsal, dengan indicator ini merupakan kemudahan bagi konsumen dalam penyewaan lapangan futsal

Assurance pada Aras Futsal seperti keamanan barang bawaan keamanan lingkungan sekitar dan keramahan dan kesopanan dan perilaku pegawai, mereka mampu meyakinkan konsumen dalam dan kemampuan dan menimbulkan kepercayaan konsumen pengguna jasa lapangan futsal pada aras futsal pekanbaru

\section{KESIMPULAN DAN SARAN}

Persepsi konsumen terhadap pelayanan pada lapangan olahraga futsal dalam kategori baik. Faktor tangible atau bukti pisik adalah penampilan pisik dan perlengkapan yang terlihat oleh konsumen dalam pelayanan penyeewaan lapangan futsal pada Aras Futsal pekanbaru hasil penelitian mengukur bahwa aspek benda berwujud pada Aras futsal ditanggai dengan baik sekali. Reability (Kehandalan)Yaitu kemampuan perusahaan dalam memberikan Pelayanan sesuai dengan yang dijanjikan secara akurat dan terpercaya, para pelanggan yang termasuk dalam penilaian ini memberikan pelayanan yang tepat waktu dan juga pelayanan yang diberikan oleh aras futsal cukup dapat diandalkan. Responsivenes (Ketanggapan) Yaitu Kemauan untuk membantu dan memberikan pelayanan, dan mencerminkan kesediaan dan personilnya untuk membantu konsumen dan memberikan jasa dengan cepat,hasil penelitian mengukur daya tanggap Aras Futsal pekanbaru adalah sangat baik. Emphaty (empati) Yaitu memberikan perhatian yang tulus dan bersifat indifidual konsumen pengguna jasa lapangan futsal pada Aras Futsal pekanbaru, penilaian aspek ini ditandai dengan adanya perhatian individual kepada setiap pelanggan dan juga memberikan jam operasional yang pleksible yang sesuai dengan kemampuan para konsumen ditanggapi dengan baik sekali. Assurance pada Aras Futsal seperti keamanan barang bawaan, keamanan lingkungan sekitar dan keramahan ,kesopanan dan perilaku pegawai, mereka mampu meyakinkan konsumen dan kemampuan dan menimbulkan kepercayaan konsumen pengguna jasa lapangan futsal pada aras futsal pekanbaru dalam mengatasi permasalahan mereka dengan tanggapan sangat baik sekali.

Untuk meningkatkan persepsi pelanggan tersebut maka perlu adanya perbaikan seperti pada faktor tangible atau bukti pisik adalah penampilan pisik dan perlengkapan yang terlihat oleh konsumen dalam pelayanan penyeewaan lapangan futsal pada Aras Futsal pekanbaru hasil penelitian mengukur bahwa aspek benda berwujud pada Aras futsal ditanggai dengan baik sekali 
Jurnal Ilmiah Ekonomi dan Bisnis

Vol. 15. No.1, Maret 2018: 84-88

EISSN : $2442-9813$

ISSN : $1829-9822$

Reability (Kehandalan)Yaitu kemampuan perusahaan dalam memberikan Pelayanan sesuai dengan yang dijanjikan secara akurat dan terpercaya, para pelanggan yang termasuk dalam penilaian ini memberikan pelayanan yang tepat waktu dan juga pelayanan yang diberikan oleh aras futsal cukup dapat diandalkan

Responsivenes (Ketanggapan)

Yaitu Kemauan untuk membantu dan memberikan pelayanan, dan mencerminkan kesediaan dan personilnya untuk membantu konsumen dan memberikan jasa dengan cepat,hasil penelitian mengukur daya tanggap Aras Futsal pekanbaru adalah sangat baik

Emphaty (empati) Yaitu memberikan perhatian yang tulus dan bersifat indifidual konsumen pengguna jasa lapangan futsal pada Aras Futsal pekanbaru, penilaian aspek ini ditandai dengan adanya perhatian individual kepada setiap pelanggan dan juga memberikan jam operasional yang pleksible yang sesuai dengan kemampuan para konsumen ditanggapi dengan baik sekali

Assurance pada Aras Futsal seperti keamanan barang bawaan, keamanan lingkungan sekitar dan keramahan ,kesopanan dan perilaku pegawai, mereka mampu meyakinkan konsumen dan kemampuan dan menimbulkan kepercayaan konsumen pengguna jasa lapangan futsal pada aras futsal pekanbaru dalam mengatasi permasalahan mereka dengan tanggapan sangat baik sekali

\section{DAFTAR PUSTAKA}

Asrori, Muhamad 2009, Psikologi pembelajaran Bandung : $\mathrm{CV}$ Wacana Prima

Ciptono Pandi 2004, Manajemen Jasa Yogyakarta . Andy Offset
Justinus Lhaksana 2011 Materi Coaching Clinic Mizone. Jakarta Difamata Sport EO

Kotler, Philip, dan Kevin Lane keller 2007 Manajemen Pemasaran Jilid I

Lupiyoadi, Rambat 2001 Manajemen Pemasaran jasa Edisi Pertama Salemba 4 Jakarta

Mifta Toha 2003 Perilaku Organisasi Konsep dasar Aplikasinya . Jakarta Grafindo Persada

Maksum, Ali. 2007. Statistik dalam Olahraga. Surabaya: UNESA

Maksum, Ali. 2009. Metodologi Penelitian dalam Olahraga. Surabaya: UNESA

Rianto Adi. (2010). Metodologi Penelitian Sosial dan hukum. Jakarta Granit 2004.

Rambat Lupiyoadi. (2006). Manajemen Pemasaran Jasa, Teori dan Praktek. Jakarta: Salemba Empat

Setiawan, Anjam. 2011. "Minat Siswa SMP ULUL ALBAB TAMAN SIDOARJO Terhadap Kegiatan Ekstrakurikuler Futsal". Skripsi tidak diterbitkan. Surabaya: UNESA

Slameto 2010 Belajar dan faktor-faktor yang mempengaruhinya. Jakarta Rineka CiptaSuharsimi Arikonto. (2002). Prosedur Penelitian Suatu Pendekatan Praktek. Jakarta: Rineka Cipta. 